International Journal of English Literature and Social Sciences
Vol-6, Issue-1; Jan-Feb, 2021
Journal Home Page: $\underline{\text { https://ijeab.com/ }}$ Journal DOI: $10.22161 /$ ijels

\title{
Impact of local arts; Bhand Pather and ladishah, on the people of Kashmir
}

\author{
Fidah Pandit
}

Department of English, cluster university, Srinagar, India

Received: 14 Nov 2020; Received in revised form: 22 Jan 2021; Accepted: 07 Feb 2021; Available online: 16 Feb 2021

(C2021 The Author(s). Published by Infogain Publication. This is an open access article under the CC BY license

(https://creativecommons.org/licenses/by/4.0/).

\begin{abstract}
Kashmir, surrounded by the hoop of mountain's is the land of folk tradition, literature, drama and dance. From its very beginning, the art and culture of Kashmir has contributed not only to the civilization of the union territory but also to the Indian heritage as well. However, with the rise of awareness and modernization, the art and culture of Kashmir is foreseen as benight. Despite being recognized internationally, some of the folk arts have lost their eminence causing the decay of the tradition of Kashmir. Where many of the youngsters are trying to revive the endangered arts, some citizens find their efforts squandering and antiquate. This paper explicitly engages in the comprehension of two Kashmir local arts, Bhand Pather and ladishah, the effect these have on the people and most essentially the majors to be taken for their revival.
\end{abstract}

Keywords—folk art, tradition, civilization, modernism, urbanization, Pather, ladishah, lost art, revival.

\section{INTRODUCTION}

\section{BHAND}

The traditional folk entertainers of India, Bangladesh and Nepal are known as Bhands, respectively. The term Bhand has its roots in a word bhana, a realistic and a satirical drama. It can be understood in two ways, one is that it is a dramatic story performed in an open field and the second one is that it is itself an entire school of drama.

In India, Bhands can be seen in the regions of Kashmir, Uttar Pradesh, and Punjab. Bhands perform in groups and enact the life of some legends or the contemporary social, political, and economical affairs in a very witty, simple and satirical way. However, this folk tradition has been lost somewhere in all these areas leaving a very huge void in the culture.

\section{Bhand Pather}

The plays of Bhands in Kashmir valley are called Bhand Pather. Pather means dramatic character and is derived from a word 'Patra'. Bhand Pather is an act or a performance in which there is hue of imitation, exaggeration and melodrama. Acting dancing and music forms the gist of Bhand Pather. The musical instruments used are Surnai, Dhol, Nagara, Thalij. Pather starts with the beating of Nagara (drum). The Nagara is followed by Dhol to intensify the music. Two very important properties for every Pather are a whip and bamboo stick, these are used as an embellishment to add dramatic images to the story in order to represent oppression in the society. The languages used in the acts are mainly Kashmiri, Punjabi, Persian, gujjari, dogri and English. Bhand Pather is hereditary, its legacy is handed down from a father to his son. In Kashmir, 72 villages are such where there are the majority of Bhands and such villages are locally called " Bhand gaam" ( Bhand villages). Bhand Pather is like a street play which is performed outside in an open field and mostly addresses the social problems to which everyone relates and also commemorates the lives of Rishis (both Hindu and Muslim Sufi sages) Bhand Pather appeals to the larger audience and has a great variety of issues be it political, social, and economical to cover upon. Based upon this stratum band Pather has many types:
1) Wattal pather
2) Angrez pather
3) Shikargah pather 

4) Darz pather
5) Lukh pather
6) Gosian pather

In an interview Mr. Mohammed Sadiq, a multiple award winning Bhand artist, expresses that the mere purpose of Bhand Pather is to entertain People. However, it cannot be denied that the entertainment it provides through the mythological stories incorporates social satire with its practical theme.

In Kashmir, Bhand Pather traces its history from the times immemorial. Back then, when the farmers used to come home all tired, the evenings used to be full of zeal, the people of the village would do Pather to entertain each other, and this would temporarily free the bored and exhausted farmer from the responsibilities of making a living. This way this dancing, singing, and acting took the form of Bhand Pather and catered the needs of audience with multiple issues of social evils. Mohammed Sadiq calls Bhand, a news reporter of earlier times, who would by the help of this performative art convey to people the matters in hand be those social, political or economical.

Bhand Pather became more famous and was performed on the occasions like agricultural festivals, religious festivals, on the first snowfall of the season, and social occasions. Moreover, this Pather was common in royal families where they would dance and act with music in background to please the whole empire. Kashmiri kings had their own theater known as "Nalyamandapa." The earliest pather written and staged were Zain-ul-abidin, Zainab Villas, Zaina Charitha.

Post tenth century stained the culture of Kashmir. After the Invasion of foreign rulers, the culture became mixed and gradually the very own culture of Kashmir was disturbed which trembled the fiber of Kashmir. This compelled the Bhands to express their anger for injustice done to a common man through these Pathers. These pathers afterwards took a political shape. And highly criticized the government and their policies. With the advent of industrialization and urbanization, very less people had an interest in pathers Which ultimately put their art form to a jeopardy.

To make a living Bhands left performing Pather and moved towards other profession as Pather couldn't sustain them financially. The condition was so bad that They moved from village to village to collect alms, so that, they could get edibles to eat. The Pather was disoriented and one big reason was that their own progeny shunned the legacy.

Kashmiri drama or Pather had to go through a lot in order to sustain but after all the hurdles be it through people or through rulers it finds its way to exist till date. In modern Era, we see the development of theaterand various companies like Maharaja Dharma Company, bought its revival. However, The Pather on roads somewhere lost the significance as when the drama is staged, One has to make it, keeping in mind, not to hurt the political heads but Bhand Pather has no such limitations. Issues like women's treatment in society, Evil Political agendas of certain parties, marriage related issues, issues related to economical decrement etc. are addressed by Bhands which otherwise remain untouched and unspoken by majority of art forms.

Bhand Pather is an integral part of cultural heritage and living culture. As a part of universal heritage it can be a great source of uniting different people and asserting their cultural identity. Therefore, major steps should be taken in order to revive this folk tradition.

First and foremost, national events should be organized where these Bhands can perform and get recognition throughout the country. Also, the international community should ensure the position for such folk artists. The artists of the Pather should be awarded frequently to protect and safeguard their identity and expand the interest of Pather in the younger generation. They should be aided financially so that they don't have to opt for some other work to make the living. Moreover, Bhand Pather should be introduced in school curricula, so that, children get acquainted with Their own traditional folk art.

Also, very less work has been done upon this art form. Therefore, it's the duty of a common man to research on Bhands and support them in practice. Otherwise, no-one in the next century would come toknow the Kashmiri traditional folk art and people would be celebrating other foreign traditional arts for centuries.

\section{LADISHAH}

Ladishah, Ladishah dari kin peow

Pewnai pewnai haptan kheow

(Ladishah, Ladishah! Fell off the window!

And a grizzly bit him just as he fell!)

Ladishah is a classical character of Kashmiri literature. It is a folk literary genre which is unlike other folk arts written and narrated by the same person. Ladishah is a form of art in Kashmir which is a particular variety of satirical ballads. According to zareef Ahmad zareef, Ladi means a row and shah means a ruler or majesty. Ladishah has a peculiar rhythm combined with sarcastic lyrics. Ladishah being the author of his lyrics would convey a particular message to people about social, economical, and political impishness blended with satire and humor. However, Ladishah does the constructive criticism which 
ultimately results into the welfare of the society. Some important recognized masters of ladishah are Hakeem Habibiullah, Munawar Shah of Kulsoo, and Lal Lakshman.

It is believed that Ladishah came into existence in the late $18^{\text {th }}$ or early $19^{\text {th }}$ century because there is no mention of this tradition art in the Rajtarangi. However, it is also believed that Ladishah traces its history from Bhand Pather, a Kashmiri traditional folk art. But ladishahs were an institution in themselves. A person wearing a white turban, pheran, a white trouser, white stole hanging on shoulder with a musical instrument called Trum Trum or Dehra, would go to rural areas to perform and would get the food to eat in return. He would in a very witty manner criticize the odds of society and people would get tempted to his droll remarks on politics and society. Ladishah was mostly the one who had no place to dwell in and would go village to village in order to get edibles by performing. With the help of the musical instrument Trum Trum, Ladishah used to call people and after the people would gather, he would narrate the issues in hand. The main topics he would touch were; political downfall, social inequality, or economic loss, human shortcomings. Main themes of ladishahs poems would be: pish nam'e, bunuil nam'e, sehlab nam'e, angrez qanoon. It is very important for Ladishah to maintain the simple and lucid language, also the ballads recited by him should contain humour and criticism simultaneously.

Zareef Ahmad zareef, is of the view that, despite being uneducated, ladishahs were the best history describers. That is why they are known as folk historians. He would debunk the system and show all the facets of life. With his witty and sarcastic remarks, he would make a plaint on leaders or rulers, and this way gained the support from the common people, which gave him more power to talk about existing evils.

But unfortunately, just like every other folk art of Kashmir, this one too faced the fear of extinction. With the advent of technology, the prominence of Ladishah lost its track. It was in very recent times that Ladishah started appearing on the television channel and people again are gaining interest in it. It inspired many Kashmiris to revive this lost folk art and one among them is Areej Safvi, who happens to be a first female Ladishah of Kashmir. Safvi says that, through ladishah she touches Many topics which otherwise aren't talked about. She has been highly Influenced by the airing of ladishah on television.

Therefore, to bring this tradition back to the track there has to be the involvement of Government in identification, conservation, preservation, dissemination, and protection of this art. Also, the international cooperation is equally important.

\section{CONCLUSION}

Both Ladishah and Bhand Pather have a huge impact on the people of Kashmir no matter to which religious sect they belong to. Therefore, in order to keep both of these art forms sustaining, people need to watch them and demand for them. Which otherwise, would vanish from the earth in a blink of an eye. There is a necessity to bring back these art forms on track so that the social, cultural, and political issues can be dealt with such art forms, and not with violence and ferocity.

\section{REFERENCES}

[1] Dr. Waheeda Akhtar, ladishah:a Kashmiri melody, national journal of multidisciplinary research and development, September 2017.

[2] Bilal Ahmad Dar, A study of Kashmiri folk singing from vanvun and ladishah, international journal of advanced educational research, November 2017.

[3] Dr. Waheeda Akhtar, Bhand Pather ( the folk Theatre of Kashmir), international journal of academic research and development, September 2017.

[4] M.k Raina, the bhand Pather of Kashmir, http://www.koausa.org/BhandPather/

[5] Syed samreen, new virtual stars, Kashmir life.net,kashmirlife.net New Virtual Stars

[6] Bhand pather, the traditional folk theatre in Kashmir, https://www.iwmbuzz.com/theater/snippets-theate... 